Director of Natural Sciences College, Lviv National University of Ivan Franko, 107 Tarnavskoho Str., 79017 Lviv, Ukraine, mariya.dzikovska@lnu.edu.ua

\title{
COACHING AS THE PEDAGOGICAL TECHNOLOGY IN PROFESSIONAL TRAINING OF FUTURE SPECIALISTS
}

The article deals with theoretical analysis of coaching - as innovative pedagogical technology. Relying on a comparative analysis of scientific and pedagogical sources, the author notes common problems in the scientific research of domestic and foreign scientists. It is pointed out that the technology of coaching went through the theoretical analysis, wide practical application in the theory and practical research by foreign scientists.

It is shown that common features in domestic and foreign studies of coaching are: the construction of educational processes based on motivational interaction; creation of opportunities to disclose individual's potential; the equitable creative activity of participants in the educational process; partnership to support people in achieving their goals.

It has been proved that coaching has all signs of pedagogical technology, common pedagogical activity model of design, organization, and introduction in the educational process; the organizational component of the structure of different forms in native classes, other types realization of pedagogical consideration of subjects in educational process; Possibility for the development of the student's personal potential and realization of teacher's potential; The stages of coaching realization on the basis of knowledge are characterized (twelve stages with realization of practical tasks on each of them).

The author identifies the benefits (enhancement of the activation of the educational process and the motivation of students to study the course, identify students' abilities that reveal them as creative people capable of logical thinking, the development of students leadership qualities and emotional intelligence, high productivity of the educational process and the improvement of communication skills) and the disadvantages of using coaching technology in the training of future specialists in a higher education institution. It is shown that coaching develops leadership skills for students, which stimulates the formation of successful teams that provide training for competent professionals in a higher education institution.

Key words: coach; coaching; coaching technology, educational coaching; education quality; training.

https://doi.org/10.28925/1609-8595.2019.3.4550

Introduction. One of the conditions for the competitiveness of a higher education institution is the availability of an internal quality system that meets the generally recognized requirements. Achieving quality professional training is conditioned by a clear organization of the educational process, the correct selection of teaching methods, techniques and technologies. According to S. Nikolaenko (2006), having a quality system in place will ensure the competitiveness of the higher education institution.

The analysis of scientific works shows that the use of innovative training technologies provides the training of highly qualified, professionally knowledgeable in their and related fields specialists who are capable of thinking logically, motivated and able to learn and selfdevelop. One such technology that provides effective training is coaching technology. Although in Ukraine the concepts of coaching in education are not receiving much attention, as is the case in many countries, we believe that this technology should be used effectively in the domestic education system.

The analysis of scientific works shows that the use of innovative training technologies helps to prepare highly qualified professionals who are well-versed in their own and related fields, capable of thinking logically, motivated and able to learn and self-develop. One of the technologies that provide effective training is coaching technology. While in Ukraine the concept of coaching in education is not yet sufficiently addressed like in many other countries around the world, we believe that this technology should be used effectively in the domestic education system.

Coaching, as the newest alternative pedagogical technology in teaching and effective technology of competence formation in students, is presented in the scientific achievements of both Ukrainian and foreign scientists. Coaching features, prospects of introduction of elements of the specified technology in the educational process of institutions of higher education are presented in studies of domestic (T. Borova, N. Goruk, S. Zhitskaya, O. Yefimova, L. Kudryk, S. Romanova, G. Poberezskaya, Y. Surmak, O. Shevchuk) and foreign (D. Druckman, R. Bjork, J. Wittmore, R. Diltts, B. Wuytsek) scientists.

Features of coaching, as technologies of professional training of experts, have induced us to carry out scientific researches in the given context. 
The purpose of the article is to analyze theoretical studies of the problem of coaching as educational and pedagogical technology and to determine the feasibility of using coaching technology in the process of professional training of specialists in higher education.

The content of the concept of «coaching». The emergence of terms such as «coaching», «educational coaching», «coaching technology» is a new phenomenon in our educational environment. Translated from English, «coach» is interpreted as «train», «inspire», «mentor».

A coach is a counseling trainer who encourages the client to make the right choice to achieve their goals.

L. Khomenko-Semenova (2015) notes that coaching develops leadership skills in students (p. 137). Of course, leaders form successful teams, and these, in turn, give the labor market a competitive product. As a result, this is a successful country with a market economy.

We agree with the opinion of S. Romanov (2010), who describes coaching as a phenomenon of educational process, built on a motivating interaction, where the teacher creates the conditions that can unlock the student's personal potential to achieve his key goals in a certain area of knowledge, in the optimal terms (p. 86).

T. Borova (2010) notes that coaching is used to unlock the individual potential in order to maximize personal productivity and work efficiency. However, it focuses on the changes and transformations of human ability to refine, to change the behavior of people who are difficult to adapt, and stimulates the birth of new, adaptive and successful actions.

Coaching, in the opinion of L. Brzeziński (2014), in education means supporting the student in his or her development, along the path throughout the education system. In the coaching method, the center of gravity shifts to the less traditional elements of the education system. This means that in the area of competence a person works not only on knowledge but also on individual, unique experience. Students are often faced with difficult situations in their lives that are not generalizable and cannot be applied to uniform standards. The purpose of a coach's action is to identify these needs, as well as to monitor the role they play in the student's life, and how these needs, through strengthening, can improve the student's social functioning. The object of a student-coach relationship is organizational and leadership practices based on collaboration with people, especially teamwork. Through coaching, a personal dimension of upbringing is created, based on the enhancement of autonomy, both in thinking and in action (p. 169).

C. Munroe (2016) describes coaching as a partnership to support people in achieving their goals. He notes that coaching conversations are deliberately guided conversations that use active listening, skillful questions and other coaching skills, enhanced by a high level of emotional intelligence, in order to raise awareness and encourage accountability in the coaching staff. The process involves explaining goals, exploring reality, options, agreement on actions, and their review and implementing. For educators coaching can be a highly personalized form of professional training that enhances learning in classes, teams, management, and even career advancement.

In our opinion, coaching in education or educational coaching is a structured interaction between teacher student, student - student, which creates opportunities for students to discover abilities, creative ideas to achieve their goals, increase the level of motivation and interest in studying the discipline.

We agree with the position of Yu. Burmaka and L. Kudryk (2016) who are considering coaching as a pedagogical technology, which is a model of joint teaching activities in designing, organizing and conducting educational process by providing a comfortable environment for the students and the teacher. It can be used to organize different types of training sessions ( $p$. 188).

G. Poberezhska (2017) states that coaching as a pedagogical educational technology is based on some equal, creative participants in the educational process and is aimed at the identification and realization of student potential to achieve high educational and professional, social, and personal development (p. 102).

Unlike other scientists, N. Goruk (2015) emphasizes that the technology of coaching should be considered not only as a pedagogical support or creation of optimal conditions for the disclosure of the individual potential, but also for the formation of self-educational competence of the individual. After all, it trains the ability to act and learn effectively, develops the skills of independent cognitive search, self-management and effective management of their own learning activities (p. 104).

L. Brzeziński (2014) notes that coaching is a process that helps people and teams to perform tasks in the most effective way. It involves developing people's strengths, bypassing internal barriers and limitations to achieve personal excellence and facilitate more effective collaboration as a team (c. 170).

So, we can say that coaching has all the features of pedagogical technology:

1) is a model of joint pedagogical activity for the design, organization and conduct of the educational process with the provision of comfortable conditions for students and teachers;

2 ) is an organic component of the structure of various forms of organization of educational lessons, realization of other types of pedagogical interaction of subjects of educational process;

3) has opportunities for developing the student's personal potential and realizing the potential of the teacher.

Practical aspects of coaching technology. Coaching, as one of the varieties of innovative educational practice, is presented in the research of O. Yefimov and S. Zhitskaya (2017). Scientists say that the main purpose of the coach, as a facilitator, is to organize a productive dialogue, which should help generate new ideas and experiences. And this, 
in turn, will push for the implementation of decisions and set professional goals (p. 4).

Thus, the coach directs the process of receiving a subjective and objectively new experience. The main task is the organization of effective pedagogical interaction, stimulation of self-awareness and rethinking of personal experience, generation of new experience and implementation of decisions made in life and professional activity. The coach helps the student independently clarify and formulate their life, professional and business goals and objectives, focus attention on developmental tasks, seek both internal and external resources, find an alternative to action, plan, check them for realism, take on responsibility for their realization, as well is oriented on the student's personality and, thus, represents an element of a personality-oriented approach.

We consider it expedient to analyze the stages of implementation of «knowledge-based coaching» described by L. Brzeziński (2014) in the context of our scientific research. In the model of «knowledgebased coaching» the author identifies twelve stages of implementation of this process. Let's characterize them.

In the first stage, participants in the educational process determine the current state in which the teacher and student analyze the student's competencies, his attitude to the educational problem (or to learning in general), areas that he cannot cope with, or decisions that he must confront.

In the second stage, the desired state is determined in a specific understanding of the level of knowledge needed to work effectively in the areas where training is being carried out.

The next, third, stage is to increase the student's motivation for development, to activate cognitive activity.

The fourth stage is to identify the reasons that explain the difference between the desired and the current state of education of the student identified in the previous stage.

In the fifth stage of the coaching process, a student development plan is created, which provides for the definition of the sequence of knowledge transfer.

The sixth stage is characterized by a selection of methods and techniques that the teacher uses to convey to students the appropriate theoretical knowledge.

In the seventh stage, they show the usefulness of this knowledge, that is, they answer: «how is knowledge applied?»; this stage involves the implementation of the didactic principle - the connection of theory with practice, learning with life.

The eighth stage is already a typical practical stage where the student uses the acquired knowledge in practice. At this point, the teacher / trainer should encourage the student to experiment and apply new behaviors and solutions that he or she has not previously considered or used.

The ninth stage is to analyze the strengths and weaknesses, the solutions used and evaluate what was good, identify and correct mistakes and weaknesses.

The tenth stage of this process involves the organization and monitoring of knowledge utilization in actions, which is combined with objective feedback from the trainer / teacher / supervisor.

The consolidation of the results is achieved at the eleventh stage of the process. The social environment in which the student operates may have a greater impact on the actions and choices he or she performs than his / her personal traits or knowledge, so the trainer, together with the student, should diagnose potential barriers to the environment and identify areas of social influence.

The last, twelfth, stage is completed after a certain time, for example, in a month, three months and six months, it consists in checking the effectiveness of the actions taken in connection with the transfer of knowledge, that is, confirming the achievement of the goal and formulating conclusions.

According to researchers, coaching is not only a technology that is used in certain circumstances; effective coaching is a method of management, a method of interaction with people, a way of thinking, a way of being. Effective coaching leads the teacher to the goal, brings pleasure and joy, which will benefit all participants in the educational process. It is a non-directional approach that promotes high quality of learning and satisfaction as a result of achieving meaningful goals. It is not only a function of transferring knowledge and learning to skills, but also the realization of the function of stimulating interest in learning, the movement to awareness, the development of strengths, the unlocking of human potential, which makes the teaching process more interesting and effective (p. 170-174).

We agree with M. Kachmarek (2013) that coaching is to assist the development of a person in need with the assistance of a trainer. The goal is to develop or improve specific professional and / or life skills. An important element of coaching is partnerships and mutual trust between the coach and the student. Coaching is a very effective tool to support effective learning. Through the coaching method, the student finds his or her own path to achieve an important goal and learns to use his potential (p. 75).

We believe that the main advantages of using coaching as a pedagogical technology are:

- increasing the activation of the educational process;

- increase of students' motivation to study the course;

- identification of students' abilities, which reveal them as creative people, capable of logical thinking;

- development of leadership skills in students;

- high productivity of the educational process;

- development of communication skills;

- development of emotional intelligence.

Almost all researchers consider the lack of time as a disadvantage of this technology. We would add an impossible individual approach to assessing learning outcomes, as learning takes place in a group form. This leads to the replacement of outdated, traditional, 
inefficient methods and technologies of teaching and learning with innovative - more pleasant. It should be noted that without the internal motivation of the student to study, and teacher to the implementation of effective professional activity, without the desire for self - improvement and self-development - it is impossible to achieve the final result-reflection. We note that coaching is a kind of method of revealing the potential of the individual in order to maximize their own productivity and efficiency.

Based on the results of numerous theoretical studies and using the accumulated practical experience, we argue that the use of coaching technology in the organization of the educational process helps the individual to learn more than it teaches. This is a successful combination of not only the method of training, but also the method of management and the method of interaction with people. Selection of research and teaching staff and recruitment of educational institutions do not provide for the introduction of separate positions of coaches for students. Therefore, we recommend to revise the content of professional competences of teachers-curators and teachers-mentors, where it is advisable to introduce a number of tasks that would reflect the position of the coach (consultant, mentor). It is also advisable to update the content of official or functional duties of scientific and pedagogical workers who organize and implement practical laboratory classes, various types of practices in the context of creating conditions for individual personal and professional development of future specialists. We believe that the gradual introduction of our practical guidelines can serve as a basis for the submission of proposals for the introduction of the necessary positioncoach-coach for students.

Therefore, we confirm usage of coaching technology in the educational process contributes to the development of professional competencies that form the specialty of the student or his professional suitability.

Conclusion. Research of effective technologies of professional training of future specialists is defining in the conditions of formation of competitiveness in society. Training of specialist should cover not only the opportunities and needs that exist for now or will be added in the near future, but also foresee his professionalism «to grow». Therefore, we see the prospects of our research in the development and implementation of guidelines for the integration of elements of various pedagogical technologies for effective training, as well as the development of a system for assessing the educational achievements of students at different stages of their education in higher education.

Taking into account individual potential opportunities in assessment of educational achievements is possible in active applying of coaching - as educational technology at which activity of the teacher (the mentor, the coach) provides research of new, the most optimum ways for achievement with a certain purpose, creation of perspective tasks for personal and professional growth.

\section{References}

Brzeziński, Ł. (2014). Coaching - możliwość wykorzystania w edukacji [Coaching - the possibility of using it in education]. Pedagogical Review, 2, 166-175 (pol).

Kaczmarek, M. (2013). Tutoring, coaching, mentoring w pracyakademickiej. Folia Pomeranae Universitatis Technologiae Stetinensis. Oeconomica, 303 (72), 73-82 (pol).

Munro, C. (2016). Coaching in education: an introduction. Management strategies for school leaders. Retrieved from http://www.growthcoaching.com.au/PDF/e-leading-chris-munro.pdf?country=au (eng).

Borova, T. A. (2010). Kouching - novitnya tehnologiya profesijnogo rozvitku naukovo-pedagogichnih pracivnikiv vishogo navchalnogo zakladu [Coaching is the newest technology of professional development of scientific and pedagogical workers of a higher educational institution]. Nauka i osvita, 7, 33-37. Retrieved from http:// scienceandeducation.pdpu.edu.ua/doc /2010/7_2010/9.pdf(ukr).

Goruk, N. (2015). Kouchyng yak efektyvna texnologiya formuvannya samoosvitnoyi kompetentnosti studentiv. Problemy pidgotovky suchasnogo vchytelya [Coaching as an effective technology for the formation of selfeducational competence of students]. Problemi pidgotovki suchasnogo vchitelya, 11 (1), 99-104 (ukr).

Efimova, O. M., Zhitska, S. A. (2017). Kouchyng yak skladova osobystisno-oriyentovanogo navchannya u profesijnij pidgotovci studentiv vyshhykh navchalnykh zakladiv [Coaching as a component of person-oriented learning in the professional training of students of higher educational institutions]. Naukovij oglyad, 4 (36), 103-112 (ukr).

Nezhinskaya, O. O., Timenko, V. M. (2015). Vykorystannya kouchyngu v systemi vyshhoyi osvity Ukrayiny [Use of coaching in the system of higher education of Ukraine]. Visnik pislyadiplomnoyi osviti, 15, 236-245 (ukr).

Nikolayenko, S. (2006). Yakist vyshhoyi osvity Ukrayiny - poglyad u majbutnye [Quality of Higher Education in Ukraine - A Look into the Future]. Svit finansiv, 3 (8). Retrieved from http://sf.tneu.edu.ua/index.php/sf/article/ view/114 (ukr).

Poberskaya, G. G. (2017). Kouchyng yak pedagogichna texnologiya studentocentrychnogo navchannya u VNZ [Coaching as a pedagogical technology of student-centered learning in higher educational institutions]. Tehnologiya i tehnika drukarstva, 4, 99-107. DOI: 10.20535 / 2077-7264.4 (58). 2017.126891 (ukr).

Romanova, S. M. (2010). Kouching - novitnya tehnologiya profesijnogo rozvytku naukovo-pedagogichnykh pracivnykiv vyshhogo navchalnogo zakladu [Coaching as a new technology in vocational education]. Bulletin of the National Aviation University. Series: Pedagogy. Psychology, 3, 83-87 (ukr). 
Surmyak, Yu. R. (2016). Pedagogichnyj kouchyng u pidgotovci studentiv-psykhologiv [Pedagogical coaching in the training of students-psychologists]. Naukovij visnik Lvivskogo derzhavnogo universitetu vnutrishnih sprav. Seriya psihologichna, 1, 187-197 (ukr).

Khomenko-Semenova, L. O. (2015). Kouchyng yak nova texnologiya v profesijnij osviti [Coaching as an effective technology for the formation of a successful student]. Bulletin of the National Aviation University. Series: Pedagogy. Psychology, 7, 137-141. DOI: 10.18372/2411-264X.7.10242 (ukr).

\title{
Література
}

Brzeziński Ł. Coaching - możliwość wykorzystania w edukacji. Przegląd Pedagogiczny. 2014. № 2. S. 166-175.

Kaczmarek M. Tutoring, coaching, mentoring w pracy akademickiej. Folia Pomeranae Universitatis Technologiae Stetinensis. Oeconomica. 2013. № 303 (72). S. 73-82.

Munro C. Coaching in education: an introduction. 2016. URL: http://www.growthcoaching. com.au/PDF/e-leadingchris-munro.pdf?country=au (дата звернення: 10.05.2019).

Борова Т. А. Коучинг - новітня технологія професійного розвитку науково-педагогічних працівників вищого навчального закладу. Наука і освіта. 2010. № 7. С. 33-37.

Горук Н. Коучинг як ефективна технологія формування самоосвітньої компетентності студентів. Проблеми підготовки сучасного вчителя. 2015. № 11 (1). С. 99-104.

Єфімова О. М., Жицька С. А. Коучинг як складова особистісно-орієнтованого навчання у професійній підготовці студентів вищих навчальних закладів. Науковий огляд. 2017. № 4 (36). С. 103-112.

Нежинська О. О., Тименко В. М. Використання коучингу в системі вищої освіти України. Вісник післядипломної освіти. 2015. № 15. С. 236-245.

Ніколаєнко С. Якість вищої освіти України - погляд у майбутнє. Свiт фінансів. 2006. № 3 (8). URL: http:// sf.tneu.edu.ua/index.php/sf/article/view/114 (дата звернення: 10.05.2019).

Поберезська Г. Г. Коучинг як педагогічна технологія студентоцентричного навчання у ВНЗ. Технологія і техніка друкарства. 2017. № 4. C. 99-107. DOI: 10.20535/2077-7264.4(58).2017.126891.

Романова С. М. Коучінг як нова технологія в професійній освіті. Вісник Національного авіаційного університету. Серія: Педагогіка. Психологія. 2010. Вип. 3. С. 83-87.

Сурмяк Ю. Р. Педагогічний коучинг у підготовці студентів-психологів. Науковий вісник Львівського державного університету внутрішніх справ. Серія психологічна. 2016. № 1. С. 187-197.

Хоменко-Семенова Л. О. Коучинг як ефективна технологія формування успішного студента. Вісник Національного авіаційного університету. Серія: Педагогіка. Психологія. 2015. № 7. С. 137-141. DOI: $10.18372 / 2411-264 X .7 .10242$.

\section{КОУЧИНГ ЯК ПЕДАГОГІЧНА ТЕХНОЛОГІЯ В ПРОФЕСІЙНІЙ ПІДГОТОВЦІ МАЙБУТНЬОГО ФАХІВЦЯ}

\author{
Дзіковська Марія, директор Природничого коледжу \\ Львівського національного університету імені Івана Франка, \\ вул. Тарнавського, 107, 79017 Львів, \\ mariya.dzikovska@lnu.edu.ua
}

У статті здійснено теоретичний аналіз коучингу як інноваційної педагогічної технологї. Автор, спираючись на порівняльний аналіз науково-педагогічних джерел, зазначає проблеми, які є спільними у наукових дослідженнях вітчизняних та зарубіжних учених. Зазначено, що технологія коучингу отримала трунтовний теоретичний аналіз та широке практичне застосування саме в теорії та практичних дослідженнях зарубіжних учених.

Показано, що спільними ознаками у вітчизняних та зарубіжних дослідженнях коучингу є: побудова освітнього процесу на мотивуючій взаємодії; створення можливостей для розкриття потениіалу особистості; рівноправна творча діяльність учасників освітнього прочесу; партнерство для підтримки людей у досягненні своїх иілей.

Доведено, що коучинг має всі ознаки педагогічної технології (модель спільної педагогічної діяльності з проєктування, організації та проведення освітнього процесу; органічна складова структури різноманітних форм організаиіӥ навчальних занять, реалізації інших видів педагогічної взаємодії суб'єктів освітнього процесу; можливість для розвитку особистісного потенціалу студента та реалізації потенційних можливостей викладача); схарактеризовано етапи реалізащіі коучингу на основі знань (дванадиять етапів із реалізацією практичних завдань на кожному із них).

Автором визначено переваги (підвищення активізацї освітнвого процесу та мотивачії студентів до вивчення навчального курсу; виявлення в студентів здібностей, які розкривають їх як креативних людей, здатних до логічного мислення; розвиток у студентів лідерських якостей та емоційного інтелекту; висока продуктивність 
освітнього процесу та удосконалення комунікаційних навичок) та недоліки використання технологї коучингу у професійній підготовці майбутніх фахівців в умовах закладу вищої освіти. Показано, що коучинг розвиває лідерські якості в студентів, що стимулюе формуванню успішних команд, які забезпечують підготовку конкурентоспроможних фахівців в умовах закладу вищої освіти.

Ключові слова: коуч; коучинг; коучинг-технологія; освітній коучинг; професійна підготовка; якість освіти.

\title{
КОУЧИНГ КАК ПЕДАГОГИЧЕСКАЯ ТЕХНОЛОГИЯ В ПРОФЕССИОНАЛЬНОЙ ПОДГОТОВКЕ БУДУЩЕГО СПЕЦИАЛИСТА
}

\author{
Дзиковская Мария, директор Колледжа естествознания \\ Львовского национального университета имени Ивана Франко, \\ ул. Тарнавского, 107, 79017 Львов, Украина, \\ mariya.dzikovska@lnu.edu.ua
}

В статье осуществлен теоретический анализ коучинга как инновационной педагогической технологии. Автор, используя результать теоретического анализа научно-педагогических источников, указывает на общие проблемы в научных исследованиях отечественных и зарубежных ученых. Отмечено, что технология коучинга получила основательный теоретический анализ и широкое практическое применения именно в исследованиях зарубежных ученых. Доказано, что коучинг имеет все признаки педагогической технологии; охарактеризовань этапы реализации коучинга на основе знаний; определены преимущества и недостатки использования технологии коучинга в профессиональной подготовке будущих специалистов в условияхвысшего учебного заведения. Доказано, что коучинг развивает лидерские качества у студентов.

Ключевые слова: качество образования; коуч; коучинг; коучинг как технология; образовательный коучинг; профессиональная подготовка.

Стаття надійшла до редакції 15.05.2019

Прийнято до друку 19.09.2019 